\title{
Measuring Inflow of Remittances in Six ASEAN Countries Using Macroeconomic Variables: Panel Data Analysis
}

\author{
Andam Rani Jintan ${ }^{1}$, Faiza Husnayeni Nahar ${ }^{2 *}$, Muhammad Azizurrohman ${ }^{3}$
}

\section{마제}

\begin{abstract}
AFFILIATION:
1,2 Department of Economics, Faculty of Economics and Business, Universitas Muhammadiyah Yogyakarta, Yogyakarta, Indonesia ${ }^{3}$ Department of Tourism, Sekolah Tinggi Pariwisata Mataram, West Nusa Tenggara, Indonesia
\end{abstract}

\section{*CORRESPONDENCE:}

faizahusnayeni@umy.ac.ic

THIS ARTICLE IS AVALILABLE IN:

http://journal.umy.ac.id/index.php/jers $\underline{s}$

DOI: 10.18196/jerss.v4i2.10102

\section{CITATION:}

Jintan, A.R., Nahar, F.H., \& Azizurrohman, M. (2020). Measuring inflow of remittances in six ASEAN countries using macroeconomic variables: Panel data analysis. Journal of Economics Research and Social Sciences, 4(2), 87-101.

\begin{abstract}
Tempted by the economic potential offered by other countries makes people flocked to get the opportunity to improve their economy. Evidenced by the large number of international migrants throughout the world, this figure is in line with the high total remittance flow that leads to their country of origin. Countries in ASEAN become remittance recipients with quite high growth each year, so it is interesting to study further. Using panel data from six countries in ASEAN in 2000-2016, per capita Gross Domestic Product (GDP), domestic inflation, exchange rates, age dependency ratios and financial development are included as variables that affect remittances. The analytical method used is panel data with Fixed Effect Model (FEM). The results of the panel data found that the independent variables, including GDP per capita, domestic inflation, exchange rates, age dependency ratios and financial developments had a positive and significant effect on remittance flows in ASEAN in the period of 2000-2016. Keywords: Remittances; ASEAN; Panel Data; Fixed Effect Model
\end{abstract}

\section{Introduction}

Making the decision to migrate is caused by the potential economic benefits that arise in the form of remittances. The main motivation of migrants from developing countries is generally related to the economic opportunities that can be obtained abroad to help the economies of families left behind in their home countries (Ronald, 2008; Piper, 2007; Ullah, 2007; De Haas, 2010. It is estimated that around 272 million people live and work outside their home countries (UNDESA, International Migrant Stocks, 2019). These numbers shows that global migrant stock from year to year is always increasing since in 1990 the number of migrants was only 153 million people (see Figure 1). With an increase in global migrant stock, this can lead to a high flow of global remittances.

Refer to figure 1, remittances increase every year as global migrant stock increases. In 1990, the amount of remittances was about 6.218 billion US dollars with 152 million migrant and keep continued to increase until 2018 by 272 million people with 67.283 billion USD of remittances. 


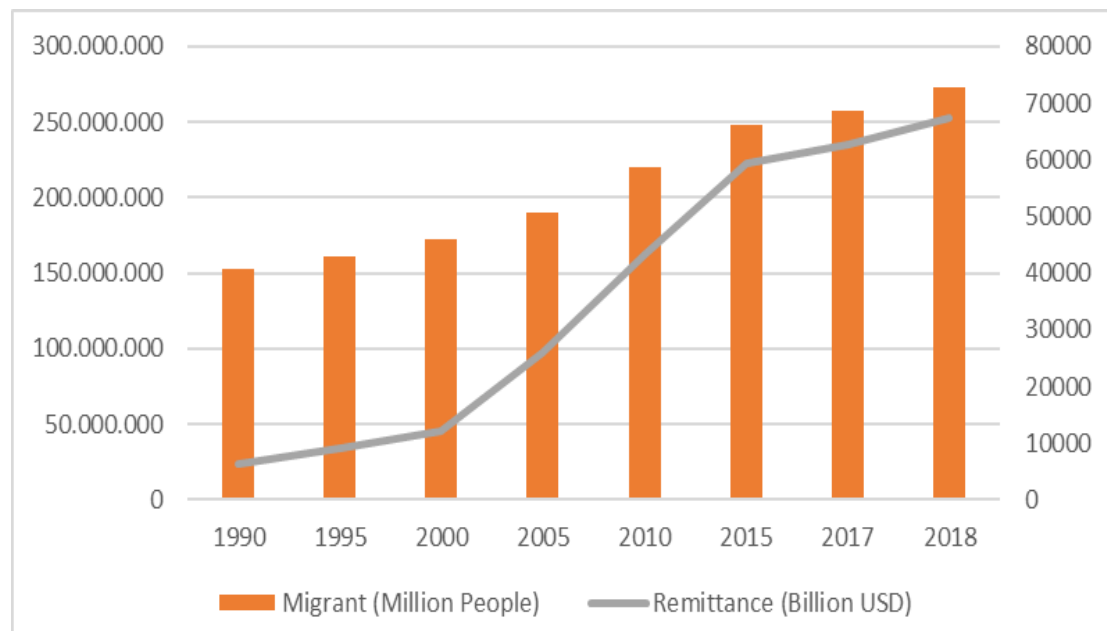

Figure 1 International Migrant Stocks dan Remittances in Period 1990-2017 Sources: UNDESA and World Bank, 2018 (processed)

Migrant remittances generally refer to transfers of cash or goods from the country where the migrant works to the household of the resident in the country of origin (Barbieri, Car, \& Bilsborrow, 2009)Referring to the IMF's Balance of Payments Manual (BPM5) in the fifth edition, there are three different categories in distinguishing remittances: (i) worker remittances, (ii) employee compensation, and (iii) migrant transfers.

Worker remittances include current transfers by migrants who work in countries visited and considered residents there. Employee compensation consists of wages, salaries and other benefits received by individuals in other countries than they currently live in. Migrant transfer refers to the transfer of financial assets made by migrants when they move from one country to another.

Later, the IMF simplified the definition of remittance and brought it in line with compilation practices that were implemented in many countries (World Bank, 2013). The six edition of the IMF Balance of Payments and the International Investment Position Manual (BPM6) introduces 'personal transfers' and 'employee compensation' for estimating remittances. Personal transfers include all current transfers between resident and non-resident individuals. The most recent remittance data published by the IMF's Balance of Payments Statistics Yearbook provides data on remittances following the BPM6 definition, namely, remittances as personal transfers and employee compensation. 


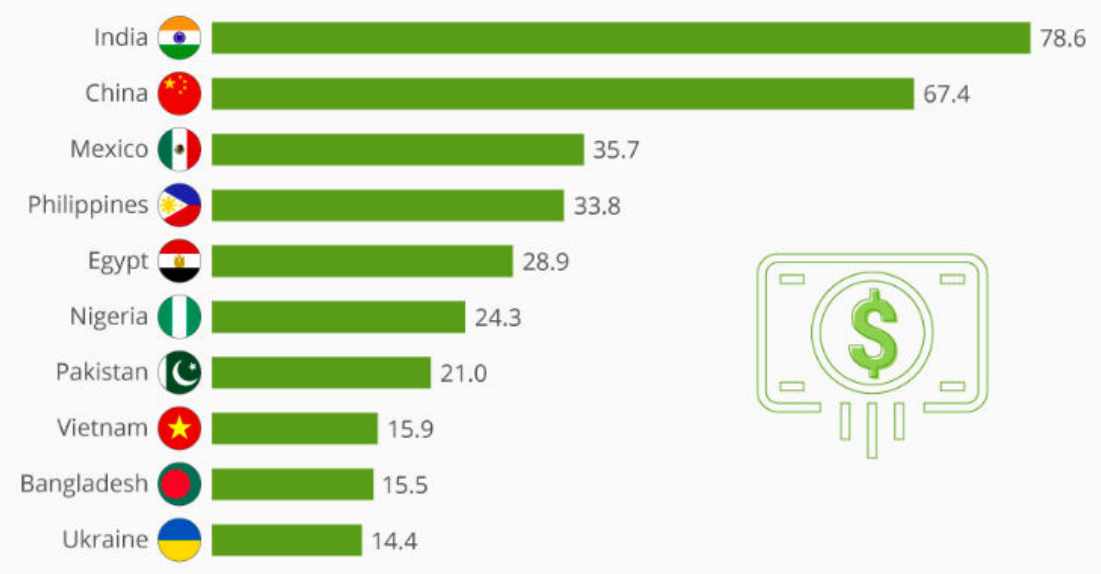

Figure 2 The World's Top Remittance Recipients in 2018 Source: World Bank Data

Referring to the Figure 2, the country that receives the largest remittances in the world is India, followed by China and Mexico. Meanwhile, Vietnam is the only ASEAN country that ranks in the top eight in the world. This is in line with the total population of those who migrate abroad.

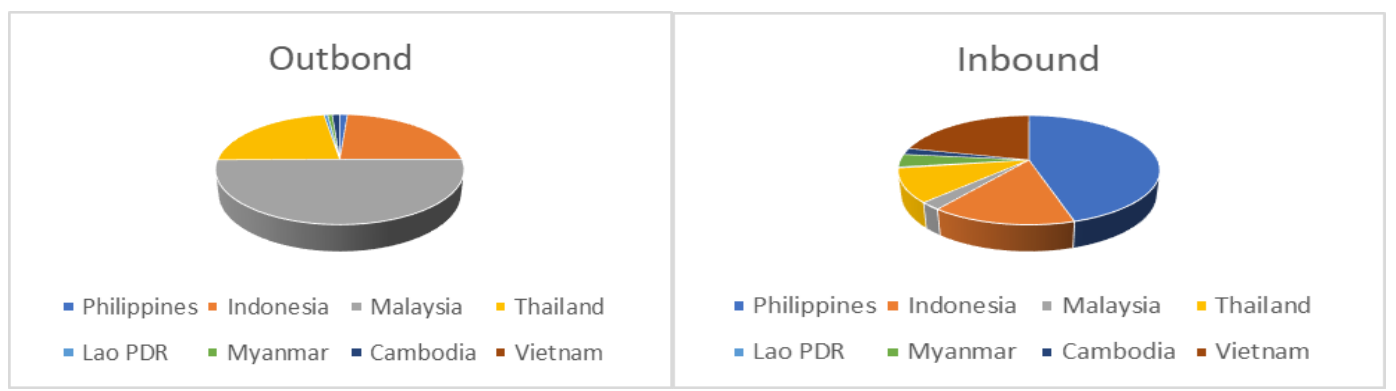

Figure 3 Remittance Inbound and Outbound of ASEAN countries in 2018 Source: World Bank Data (Processed)

Based on the inbound and outbound of remittances in ASEAN in Figure 3, the Philippines became the largest recipient of remittances in ASEAN in 2018 followed by Vietnam, Indonesia and Vietnam. Receipts from Philippine money transfer accounts are more than half of the total money transfer receipts in ASEAN. At the same time, shipping outflows from Malaysia are greater than inflows. This is because more migrants enter Malaysia compared to other ASEAN countries. The increase in remittance flows to ASEAN countries due to an increase in migrant stock and the policies of each country in ASEAN, the Philippines is one example. The Philippines is the largest recipient of remittances in ASEAN. The reason why the Philippines is the highest recipient of remittances in ASEAN is because the Philippine government has increased the competence of migrant workers so that it can increase migrant salaries. In addition, the Philippine government also focuses on providing protection, where migrants are connected in the employment information system so that the presence and condition of 


\section{Jintan, Nahar, \& Azizurrohman \\ Measuring Inflow of Remittances in Six ASEAN Countries Using Macroeconomic Variables: ...}

migrants is monitored from their countries (Fagerhim, 2015). In addition, determining factors such as the condition of the country of origin and the destination country of migrants can also affect the size of remittances sent. These factors can be seen from the perspective of the level of macroeconomics and microeconomics.

The perspective of remittances from the macroeconomic level can be seen from the level of income in sending and receiving remittances, exchange rates, inflation, economic conditions in receiving and sending remittances (Mouhoud, Oudinet, \& Unan, 2008), the ratio of engagement, and financial sector development (Fonchamnyo, 2012). The income level becomes an important variable because it can affect the amount of money sent. Chami, Barajas, Cosimano, Fullenkamp, Gapen, and Montiel (2008) use the difference in income levels between sending and receiving recipient countries. The greater the gap or the difference in the level of income that reflects the level of income in the sending country rises or the level of income in the recipient country remittances go down, then it can encourage money transfers.

In addition to the level of income, factors that affect remittances can also be seen from the level of inflation and the dependency ratio of the recipient countries. Remittances tend to increase when inflation in the recipient country also increases. High inflation rates reflect the needs of families tend to increase when prices rise while the income is fixed (El-Sakka \& McNabb, 1999). Therefore, to maintain the average family income level, migrants will send more remittances.

In terms of dependency ratios, increasing dependency ratios in a country occur along with increasing dependence on its people. This is illustrated by the number of family members who depend themselves on their families who become migrants. This is consistent with research from Fohnchamnyo (2012) who reported that the more family members who depend on migrants, the more remittances will be sent to their families in their home countries.

In terms of the remittance transfer process, financial sector development can also affect remittances sent to their families in the country of origin. The more inclusive the quality of a country's financial sector shows that the process of sending money is easier. In addition, if transaction costs are getting cheaper, it causes more remittances sent (Sign, Haacker, \& Lee, 2009). Whereas in the microeconomic level it can be seen from the perspective of migrant households, namely the education level of migrants, the pattern of remittance delivery and how remittances are used (Carling, 2008).

Research on the factors that influence remittances using macroeconomic variables has been carried out by previous researchers such as Elbadawi and Rocha (1992), El-Sakka and McNabb (1999), Aydas, Neyapti, and Metin-Ozcan (2005), Alleyne (2006), Hasan (2008), Mouhoud et al. (2008), Sign, Haacker, \& Lee, (2009) and Fonchamnyo (2012). One of them is Hasan (2008) who examines the flow of remittances in Bangladesh that uses macro variables such as inflation rates and interest rates in recipient countries, currency exchange rates, and average income levels in remittance sending countries. The results show that interest rates, exchange rates, and average income levels in 
remittance-sending countries have a positive and significant effect on remittances, but inflation has a negative effect on remittances.

Remittances in ASEAN countries are one source of external funding that has high growth and inflows. Therefore, it is important to have research on the flow of remittances that not only discusses individual countries but as a whole like ASEAN

\section{Literature Review and Hypotheses Development}

One way to improve the economy of a country especially developing countries is by remittance. Remittance is the second largest source of foreign exchange after foreign investment, it is because remittances have a character that tends to be stable so that it can help the government in dealing with the monetary crisis (Nahar \& Arshad, 2017).

Many researchers have conducted studies on the factors that influence remittance. one of them is Chami et al. (2008), the results of their study showed that the exchange rate had a negative and significant effect on remittance, the difference in interest rates had no significant effect on remittance and the difference in income had a positive and significant effect on remittance. The greater the gap or the difference in income that shows an increase in the income of the sending country or a decrease in income in the recipient country, the more remittances sent.

In the Caricom case, Alleyne (2006) examined the motivation to send remittances using the Generalized Method of Moments (GMM) method, the results of his study concluded that the GDP of recipient countries was the main motive for sending remittances. The average GDP of remittance-sending countries has a positive and significant effect on remittances, where when there is an increase in the income of remittance-sending countries, the money sent also increases. In addition, the exchange rate has a positive effect on remittances, when there is a devaluation or decline in the value of the domestic currency against foreign currencies causing more remittances or money sent to the country of origin.

Research on macroeconomic factors affecting remittances by migrants in Eastern and Southern Mediterranean countries such as Turkey, Algeria, Morocco, Tunisia and Egypt were conducted by Mouhoud et al. (2008). The method used is Error Correction Models (ECM). The purpose of this research is to find out which motives dominate migrants' decisions to send remittances between altruism, insurance or investment motives. The results show that the insurance motive is the most dominant motive in terms of remittances.

Aydas et al. (2005) examined the determinants of remittance by workers in Turkey. The results of their study show that the level of income in remittance-sending countries and differential interest rates has a significant positive effect on remittance. While the level of income in the recipient countries of remittances, inflation, black market premiums and periods of the military regime negatively affect remittances. In a study conducted by 
Hasan (2008) in Bangladesh concluded that interest rates, exchange rates and GDP had a significant positive effect on remittance inflows. Inflation rate is negative and significant towards remittances.

El-Sakka and McNabb (1999) also analyzed the flow of remittances in Egypt using the average variable level of income of the remittance-sending, inflation and interest-rate countries. The results showed that the average income of countries sending remittances and inflation had a positive effect on the level of remittances. Whereas differential interest rates have a negative and significant impact on remittances. In the case of North Africa and Europe, Elbadawi and Rocha (1992) examined the factors affecting remittance transfers from the five most labor exporting countries in North Africa and Europe such as Morocco, Portugal, Tunisia, Turkey, and Yugoslavia. They reported that the average per capita GDP of remittance-sending countries, the number of migrant workers and the length of stay had a significant positive effect on remittances while inflation had a negative and significant effect on remittances. In the case of sub-Saharan African countries, Fonchamnyo (2012) analyzed the altruistic motives for sending money using the panel data method. The results show that the difference in GDP per capita, financial sector development, differential interest rates, inflation, dependency ratios, and religion have a positive and significant effect on remittances.

Sign et al. (2009) in the same country as Fonchamnyo (2012) showed that the income of remittance-sending countries, the number of migrants and the development of the financial sector had a significant positive effect on remittances. Meanwhile, state income receiving remittances, exchange rates and differential interest rates has a significant negative effect on remittances.

In cases in ASEAN countries, Hor and Pheang (2017) examined cases in CLMV countries (Cambodia, Laos, Myanmar and Vietnam). This study uses Fixed Effect and Random Effect models in panel data for the period 2000-2015. The results of the study report that GDP per capita, exchange rate, and political stability index in the country of origin have a negative and significant effect on remittance inflows to these countries. Migrant stock can increase remittances, GDP per capita of destination countries such as Japan, South Korea and Singapore have a positive and significant effect on remittances, except Thailand's GDP per capita.

In the case in Indonesia, especially in Kendal district, Awalia (2014) reported that income, family needs, and shipping costs had a positive and significant impact on sending remittances to migrant workers. While the number of dependents does not have a significant effect on the remittances of migrant workers. The same thing was done by Apriliana \& Meydianawathi (2013) in Indonesia (Bali), they reported that the amount of income and family needs in the area of origin had a positive and significant effect on remittances sent by migrant workers. While the consumption of migrant workers, the US dollar exchange rate and the cost of remittances have a negative and not significant effect on remittances. 


\section{Research Method}

This research was conducted in six ASEAN countries such as Indonesia, Malaysia, Thailand, Vietnam, the Philippines and Cambodia. The other four ASEAN member countries namely Laos, Myanmar, Brunei Darussalam and Singapore are not included in the object of study because data is not available. The variable used in this study is remittance as the dependent variable, while the independent variables used are GDP per capita, inflation, exchange rates, budget ratios and financial sector development. The analysis used in this study uses panel data analysis from 2000 to 2016. All data were collected from World Bank website.

Here is the model equation:

$$
R E M_{i t}=\alpha+b_{1}{\log G D P_{i t}}+b_{2} I N F_{i t}+b_{3} \operatorname{LogEXCH}_{i t}+b_{4} A D_{i t}+b_{5} F D_{i t}+e
$$

Note:

REMit : Remittance per GDP (\%)

a : Constanta

LogGDP : Difference in GDP Capita (USA with six ASEAN countries)

INF : Inflation rate in six ASEAN countries (\%)

LogEXCH : Exchange Rate of six ASEAN countries

AD : : Dependency Ratio (\%)

FD : : Development of financial sector (\%)

e : : Error term

t : : Time

i : Country

\section{Result and Discussion}

Using panel data estimation, the authors investigate the effect of macroeconomic variables on remittances flow in six countries of ASEAN within 200-2016. This section contains the classic assumption test, model selection test, results estimation, and discussion.

\section{Classic Assumption Multicollinearity Test}

To detect the presence of multicollinearity is done by testing the partial correlation between the independent variables. A good model is that there is no multicollinearity between the independent variable and the dependent variable (Gujarati, 2007). One way to find out multicollinearity in the model is to look at the correlation coefficient of computer output. If the correlation coefficient is greater than 0.08 then there are symptoms of multicollinearity. 
Measuring Inflow of Remittances in Six ASEAN Countries Using Macroeconomic Variables: ...

Table 1 Multicollinearity Test

\begin{tabular}{cccccc|}
\hline Variables & LOGGDP & INF & LOGEXCH & AD & FD \\
\hline LOGGDP & 1.000000 & 0.337065 & 0.651147 & 0.094505 & -0.459753 \\
INF & 0.337065 & 1.000000 & 0.430243 & -0.064602 & -0.217452 \\
LOGEXCH & 0.651147 & 0.430243 & 1.000000 & 0.095853 & -0.552233 \\
AD & 0.094505 & -0.064602 & 0.095853 & 1.000000 & -0.730848 \\
FD & -0.459753 & -0.217452 & -0.552233 & -0.730848 & 1.000000 \\
\hline
\end{tabular}

Source: Eviews (Processed)

Based on Table 1, the values of each variables are in under $10 \%$. Therefore, it can be concluded that there is no multicollinearity problem in the model.

\section{Heteroscedasticity Test}

To check whether there is a problem of heteroscedasticity in the model, it is necessary to do the heteroscedasticity test using white test.

Table 2 Heteroscedasticity Test

\begin{tabular}{cc}
\hline Variables & Prob \\
\hline LOGGDP & 0.8760 \\
INF & 0.2867 \\
LOGEXCH & 0.5510 \\
AD & 0.1063 \\
FD & 0.2105 \\
\hline
\end{tabular}

Source: Eviews (processed)

From the Table 2, the values of all variables are above $5 \%$. Therefore, we can report that there is no heteroscedasticity problem in this model.

\section{Model Selection \\ Chow Test}

Chow tests are carried out to determine the most appropriate model between Ordinary Least Square (OLS) and Fixed Effect (FE). If the result cannot reject the null hypothesis, the most appropriate model to use is OLS. Conversely, if the results reject the null hypothesis, the most appropriate model to use is to use a Fixed Effect.

Table 3 Chow Test

\begin{tabular}{lccc}
\hline Effects Test & Statistic & d.f & Prob. \\
\hline Cross-section F & 296.566162 & $(5,85)$ & 0.0000 \\
Cross-section Chi-square & 279.820515 & 5 & 0.0000 \\
\hline
\end{tabular}

Source: Eviews (processed)

Based on the results of the chow test, it can be seen that the probability value of Crosssection $\mathrm{F}$ and Cross-section Chi-Square is 0.0000 less than 0.05 , which means null hypothesis is rejected. Therefore, the best method that can be used is the Fixed Effect model. 
Measuring Inflow of Remittances in Six ASEAN Countries Using Macroeconomic Variables: ...

\section{Hausman Test}

Hausman Test is used to determine what method is most appropriate to be used between a Fixed Effect or Random Effect model. If the results cannot reject the null hypothesis, then the most appropriate model to use is the Random Effect.

Table 4 Hausman Test

\begin{tabular}{cccc}
\hline Test Summary & Chi-Sq. Stat & Chi-Sq. df & Prob. \\
\hline Cross-section random & 1482.830784 & 5 & 0.0000 \\
\hline
\end{tabular}

Source: Eviews (processed)

Based on the table 4, the value of the cross section random is 0.0000 less than 0.05 , which means the null hypothesis is rejected. Therefore, the best model that can be used is the Fixed Effect method.

Based on the model specification test that has been done using the Chow test and Hausman test, the results show that the Fixed Effect model is the best.

Table 5 Empirical Results

\begin{tabular}{llll}
\hline Variables & \multicolumn{1}{c}{ Model } & \\
\cline { 2 - 4 } & \multicolumn{1}{c}{ Common Effect } & \multicolumn{1}{c}{ Fixed Effect } & Random Effect \\
\hline Constanta & $-153.792^{* * *}$ & $-45.856^{* * *}$ & $-153.792^{* * *}$ \\
LOGGDP & $13.873^{* * *}$ & $2.640^{* *}$ & $13.873^{* * *}$ \\
INF & $0.144^{*}$ & $0.050^{* * *}$ & $0.144^{* * *}$ \\
LOGEXCH & $-0.513^{* * *}$ & $2.512^{* * *}$ & $-0.513^{* * *}$ \\
AD & $0.228^{* * *}$ & $0.097^{* * *}$ & $0.228443^{* * *}$ \\
FD & $0.022^{*}$ & $0.017^{* * *}$ & $0.022^{* * *}$ \\
R $^{2}$ & 0.484 & 0.972 & 0.484 \\
F-Stat & 16.892 & 295.420 & 16.892 \\
Prob(F-Stat) & 0.000 & 0.000 & 0.0000 \\
Durbin-Watson Stat & 0.124 & 0.879 & 0.124 \\
\hline
\end{tabular}

Source: Eviews (processed)

Note: ${ }^{*}=$ p-value $<0.10, * *=p-$ value $<0.05 * * *=p-$ value $<0.001$

Based on Table 5, the difference in GDP per capita (between the United States and six ASEAN countries) shows a significant positive sign of 5 percent confidence level for the six ASEAN countries. The coefficient on GDP per capita difference has a value of 2,640, which means that if the increase in the GDP per capita difference is $1 \%$ while the other variables are fixed, then remittance inflows will increase by $2.64 \%$.

In the study of Siegfried and Schiopu (2006) income differences have a positive significant impact on remittances. Positive results indicate that remittances have countercyclical properties. Countercyclical is defined as economic variables that move in the opposite direction to real GDP where the value of the variable decreases when it expands and increases during a recession (Hubbard, O'Brien, \& Rafferty, 2014). Fonchamyo (2012) and Putra (2016) reported that remittances will increase when there is a large income gap between the six ASEAN countries and the United States and will 
decrease when the income gap shrinks (Fonchamnyo, 2012). Migrants will send more remittances to the recipient country when the income level of the receiving country is lower relative to the sending country. This is in line with theories that show the motive for altruism in sending money. Altruism is the desire to prioritize the interests of others where migrants are very concerned with the conditions experienced by migrant households (Lucas \& Stark, 1985). When migrant income in the country where he works increases, the amount of remittances sent to the country of origin will also increase. Migrant families can meet the necessities of life more than usual because they get more income than before. The need for consumption can be fulfilled to the maximum and most likely the need for investment can also be met.

According to Hamidah (2013), remittances are widely used for consumer needs by 56 percent while investments by 44 percent. Consumption needs are widely used for household, car and motorcycle purchases. While the fulfillment of investment needs is carried out for agriculture, animal husbandry and businesses in the field of daily necessities. So that the needs of migrant families, both consumption and investment, make the remittances sent by workers abroad unnecessary in large numbers. Zanker and Siegel (2007) say that as the income of the worker's family in the home country becomes more established, workers can reduce the amount of remittance to be sent. For instance, when a father working in the Middle East leaves his wife and children, he will send as many remittances as possible to meet the needs of his family. When the necessities of life can be fulfilled, then the needs for the future, such as education, health, insurance, etc. can be met afterwards. This is also consistent with the theory of pure self-interest which states that remittances can be an indirect inheritance, because the money sent can increase investment and will prosper the children or even grandchildren of migrant families. So that in the end the amount of remittances sent will slowly decrease with the income of migrant families in their home countries.

Based on item Table 5, it can be explained that the inflation variable (INF) shows a significant positive sign at $1 \%$ significant level for six ASEAN countries. The coefficient value of the inflation variable is 0.050 which means that if there is an increase in inflation of $1 \%$ while the other independent variables are considered constant, the remittance inflows in the six ASEAN countries will increase by $05 \%$ percent. Positive coefficient values indicate a positive influence between inflation and remittance inflows in six ASEAN countries.

There are several explanations regarding the positive impact of inflation on remittances. First, when the inflation rate rises, the community's needs will increase, so that remittances sent to migrant families will increase. According to Fonchamnyo (2012), the level of domestic inflation reflects the level of macroeconomic instability. Inflation is a process of increasing prices of goods as a whole and continuously caused by the decline in the value of money in a certain period of time (Basuki \& Prawoto, 2014). When there is inflation, people will have difficulty in getting the same quantity of goods and services. People who have low and medium incomes will feel the direct impact of significant inflation. According to Nahar and Arshad (2017), low-income and middle-income people will not increase as inflation continues to rise. Therefore, with the fixed income, the 


\section{Jintan, Nahar, \& Azizurrohman \\ Measuring Inflow of Remittances in Six ASEAN Countries Using Macroeconomic Variables: ...}

goods and services obtained by the community will be less than usual. When inflation rises, the amount of remittances sent will increase as society's needs get higher in getting goods and services.

Second, inflation supports the altruism motive for remittances, where an increase in inflation has a negative effect on the real income of the family in the country of origin so that the need for more money inflows, the more remittances sent to reduce the negative effects of inflation on the economic welfare of the family in country of origin (Mouhoud et al., 2008). Therefore, when the economic condition of the original family experiences a problem, migrants will send more remittances.

However, this is different from the research conducted by Elbadawi and Rocha (1992), Aydas et al. (2005), and Hasan (2008) which stated that inflation has a negative effect on remittance inflows. According to Aydas et al. (2005), investment is the most effective motive in terms of remittance delivery in Turkey. In the case of Europe and North Africa, inflation also has a negative effect on remittance inflows because inflation is a bad signal for the investment climate in remittance recipient countries. This is because when the prices of goods and services on the market are very high, the tendency of people to consume these goods and services will decrease. When prices on the market go up and are not accompanied by an increase in income to society, it can cause people's consumption to fall. With the decline in public consumption, it can cause a decrease in production. This can cause investors to rethink in investing their capital. Therefore, workers will think twice about sending remittances that are intended for investment because of the low return on investment due to inflation (Elbadawi \& Rocha, 1992).

Based on Table 5, it can be explained that the exchange rate variable shows a significant positive sign at $1 \%$ significant level for six ASEAN countries. The coefficient value of the exchange rate variable is 2,512 which means that if there is an increase in the exchange rate of $1 \%$ while the other variables are considered constant, the remittance inflows in the six ASEAN countries will increase by $2.51 \%$.

Depreciation of a country's exchange rate against other countries can have positive and negative impacts. The negative impact of the exchange rate depreciation is that it can increase inflation caused by an increase in public consumption of imported goods, so that foreign exchange issued by a country is even greater. Producers who use imported raw materials will experience an increase in production costs so that the goods sold also increase. These negative impacts can complicate people's lives, especially the lower middle class.

However, exchange rate depreciation can also have a positive impact. One of the positive effects of exchange rate depreciation is the increase in remittances. The depreciation of the exchange rate can help migrant families in reducing the negative effects of inflation because more and more remittances are received which can ultimately help reduce the number of poor people (Nahar \& Arshad, 2017). 
This is consistent with the hypothesis that the exchange rate has a positive effect on remittance inflows in six ASEAN countries. This study is in line with research conducted by Faini (1994), Aydas et al. (2005), Alleyne (2006), and Yang (2008) where there is a significant influence between exchange rates and remittance inflows. When the exchange rate of a recipient's country of remittance depreciates, the amount of remittance received will increase.

In contrast to research conducted by Sign et al. (2009) Fonchamnyo (2012) and Hor and Pheang (2017), the results showed that the exchange rate had a negative effect on remittances. According to Hor and Pheang (2017), this negative influence explains that migrants might delay or reduce the amount of remittances sent to their home countries to avoid losing exchange rates during currency appreciation which shows the strong economic conditions of the country of origin. Conversely, migrants send more remittances to benefit from exchange rate depreciation which shows the adverse economic situation of the country of origin.

Based on Table 5, it can be explained that the variable dependency ratio shows a statistically significant positive sign at $1 \%$ significant level for six ASEAN countries. The coefficient value of the dependency ratio variable is 0.097 which means that if there is an increase in the dependency ratio by 1 percent while the other independent variables are considered constant, the remittance inflows in the six ASEAN countries will increase by $09 \%$.

This is consistent with the hypothesis that the dependency ratio has a positive effect on remittance inflows in six ASEAN countries. In line with research conducted by Fonchamnyo (2012) where there is a significant influence between the dependency ratio and remittance inflows. According to Fonchamnyo (2012) the dependency ratio reflects the number of dependents in the working age population. This shows the altruism motive in remittance due to the large need to pay for family members who are poor and unemployed.

In contrast to research conducted by Awalia (2014), the results of the study showed that the number of dependents had no effect on remittances. According to Awalia (2014) this is because migrants who work outside their home country are mostly not the backbone of the family. Remittances sent to families in the country of origin are only to help the economy of the people covered by migrants, but not all the needs of the people covered are from migrants. Migrants only send remittances according to their respective abilities.

Based on Table 5, it can be explained that the financial sector development variable shows a statistically significant positive sign at 1 percent significant level for six ASEAN countries. The coefficient value of the financial sector development variable is 0.017 which means that if there is an increase in financial sector development by $1 \%$ while the other independent variables are considered constant, the remittance inflows in the six ASEAN countries will increase by $01 \%$. 
Development of the financial sector is one of the keys of the economic function in seeing the conditions of development with economic growth and poverty reduction (Karikari, Mensah, \& Harvey, 2016). Development and deepening in the financial sector are key elements to differentiate developed and developing countries (Almarzoqi, Naceur, \& Kotak, 2015). Financial development is a policy, factor and institution that plays an important role in increasing financial efficiency and intermediation and success in financial markets (Adnan, 2010).

The financial sector is an indicator in measuring the quality of a country's financial sector. Research conducted by Mckinnon (1973) and Shaw (1973) in Lynch (1993) shows that ineffective financial sectors have an impact on limitations in economic development. Inadequate financial sector causes expensive money transfer transaction fees. For example, a migrant in Singapore wants to send money to a family in Indonesia of 300 SGD and a remittance transaction fee of 15 SGD. This means that the total amount of money to be sent is 285 SGD. Because transaction costs are expensive, migrants prefer to send money through the informal sector or the non-financial sector (Nahar and Arshad, 2017). While an adequate financial sector can increase remittances due to easier access, resulting in increased remittances. This is consistent with the hypothesis that financial sector development has a positive effect on remittance inflows in six ASEAN countries. In line with research conducted by Sign et al. (2009) and Fonchamnyo (2012). According to Sign et al. (2009) developing a good financial sector in a country can facilitate the process of sending money and can reduce costs associated with sending money, thereby increasing the amount of money sent.

When referring to the R-square value in Table 5 which is worth 0.972 , it can be concluded that $97 \%$ of variants in this model can explain the flow of remittances in six ASEAN countries. While the remaining $3 \%$ is outside the model.

\section{Conclusion}

Making the decision to migrate is caused by the potential economic benefits that arise in the form of remittances. The main motivation of migrants from developing countries is generally related to the economic opportunities that can be obtained abroad to help the economies of families left behind in their home countries. This is certainly interesting to discuss further in order to create more knowledge about remittances in ASEAN countries. Using panel data regression from six ASEAN countries in the period 20002016.

The results prove that differences in GDP per capita, inflation, exchange rates, dependency ratios, and development of the banking sector have a significant positive effect on remittance inflows in six ASEAN countries for the period 2000-2016. Based on the research results and conclusions, it would be better if the government improved the quality of migrants such as providing education and skills training. Higher education will help migrants to achieve higher levels of employment, so they have competitiveness against other migrants. Thus, the income received by migrants will increase along with 
the increased ability they have which will ultimately increase remittances sent. In addition, the government is expected to improve the quality of its financial sector where the financial sector is an intermediary in remittance transfers. A good financial sector will make it easier for migrants to send money and transaction costs incurred will also be cheaper.

\section{References}

Adnan, N. (2010). Measurement of financial development: a fresh approach. 8th international conference on Islamic economics and finance. Center for Islamic Economics and Finance, Qatar Faculty of Islamic Studies, Qatar Foundation.

Alleyne, D. (2006). Motivations to remit in caricom: a gmm approach. Social and Economic Studies, 55(3), 69-87. Retrieved from http://www.jstor.org/stable/27866471

Almarzoqi, R. M., Naceur, S. B., \& Kotak, A. (2015). What Matters for Financial Development and Stability. IMF Working Paper.

Apriliana, D., \& Meydianawathi, L. G. (2013). faktor-faktor yang mempengaruhi pengiriman remitansi TKI asal Bali di Amerika Serikat. E-Jurnal Ekonomi Pembangunan Universitas Udayana, 2(8), 373-383. https://ojs.unud.ac.id/index.php/eep/article/view/5861

Awalia, N. (2014). Faktor faktor yang mempengaruhi pengiriman pendapatan tenaga kerja indonesia ke keluarga di Kabupaten Kendal. Economics Development Analysis Journal, 3(1). https://doi.org/10.15294/edaj.v3i1.3518

Aydas, O. T., Neyapti, B., \& Metin-Ozcan, K. (2005). Determinants of workers remittances: The case of Turkey. Emerging Markets Fince and Trade, 41(3), 53-69. https://doi.org/10.1080/1540496x.2005.11052609

Barbieri, A. F., Carr, D. L., \& Bilsborrow, R. E. (2008). Migration within the frontier: The second-generation colonization in the Ecuadorian amazon. Population Research and Policy Review, 28(3), 291-320. https://doi.org/10.1007/s11113-008-9100-y

Basuki, A. T., \& Prawoto, N. (2014). Pengantar teori ekonomi. Yogyakarta: Mitra Pustaka Nurani.

Carling, J. (2008). The determinants of migrant remittances. Oxford Review of Economic Policy, 24(3), 581-598. Retrieved from http://www.jstor.org/stable/23606904

Chami, R., Barajas, A., Cosimano, T., Fullenkamp, C., Gapen, M., \& Montiel, P. (2008). Macroeconomic consequences of remittances. Washington DC: International Monetary Fund.

De Haas, H. (2010). Migration and development: A theoretical perspective. International Migration Review, 44(1), 227-264. https://doi.org/10.1111/j.1747-7379.2009.00804.x

Elbadawi, I. A., \& Rocha, R. D. (1992). Determinants of Expatriate Workers Remittances in North Africa and Europe. Country Economics Department the World Bank.

El-Sakka, M. I. T., \& McNabb, R. (1999). The macroeconomic determinants of emigrant remittances. World Development, 27(8), 1493-1502. https://doi.org/10.1016/s0305750x(99)00067-4

Fagerhim, M. G. (2015). Impact of remittances on economic growth. Thesis for Master Philosophy in Environmental and Development Economics.

Fonchamnyo, D. C. (2012). The altruistic motive of remittances: A panel data analysis of economies in sub Saharan Africa. International Journal of Economics and Finance, 4(10). 192-200. https://doi.org/10.5539/ijef.v4n10p192

Gujarati, D. (2006). Basic econometrics (ekonometrika dasar). Jakarta: Erlangga. 
Hasan, M. M. (2008). The Macroeconomic Determinants of Remittances in Bangladesh. MPR A Paper Institute of Microfinance (INM), Dhaka, Bangladesh. Retrieved from https://mpra.ub.uni-muenchen.de/id/eprint/27744

Hor, C., \& Pheang, P. (2017). Analysis Determinant Factor Effect on Migrant Workers Remittances Flow to the CLMV Countries. International Journal of Economics and Financial Issues, 7(2), 202-207.

Hubbard, R. G., O'Brien, A., \& Rafferty, M. P. (2014). Macroeconomics, 2nd edition. Essex: Pearson Education Limited.

Karikari, N. K., Mensah, S., \& Harvey, S. K. (2016). Do remittances promote financial development in Africa? Springer Plus, 5(1011), 1-21.

Lucas, R. E., \& Stark, O. (1985). Motivations to remit: evidence from Botswana. Journal of Political Economy, 93(5), 901-918. https://doi.org/10.1086/261341

Lynch, D. (1993). Alternative measures of financial development. Center of Study Money, Banking, and Finance Macquaire University, 1-31.

Mckinnon, R. I. (1973). Money and capital in economic development. Washington D.C: The Brooking Institution.

Mouhoud, E. M., Oudinet, J., \& Unan, E. (2008). Macroeconomic determinants of migrant's remittances in the southern and eastern mediteeanean countiries. Working paper CEPN .

Nahar, F. H., \& Arshad, M. N. M. (2017). Effects of remittances on poverty reduction: The case of indonesia. Journal of Indonesian Economy and Business, 32(3), 163-177. https://doi.org/10.22146/jieb.28678

Piper, N. (2007). Governance of migration and renationalization of migrants' rights - an organizational perspective. Paper Presented at the Conference on 'Renationalization and Development(s): Towards a North-South Perspective', Center for Interdisciplinary Research, (pp. 1 24).

Putra, A. W. (2016). Analisis faktor - faktor yang mempengaruhi remitansi di Kabupaten Cilacap. Economics Development Analysis Journal, 5(3), 278-286. https://doi.org/10.15294/edaj.v5i3.22150

Ronald, S. (2008). Migration and development. Thailand: Population Division.

Shaw, E. S. (1973). Financial deepening in economic development. New York: Oxford University Press.

Siegfried, N., \& Schiopu, I. C. (2006). Determinants of workers' remittances: evidence from the European neighboring region. ECB Working Paper No.688, 1-34.

Sign, R. J., Haacker, M., \& Lee, K. W. (2009). Determinants and macroeconomic impact of remittances in sub-Saharan Africa. IMF Working Paper WP.

Ullah, A. A. (2007). Rationalizing migration decisions: Labour migrants in East and SouthEast Asia. Disertation. City University of Hong Kong, 1-347.

Zanker, J. H., \& Siegel, M. (2007). The determinants of remittances: A review of the literature. MGSoG Working Paper No. 003. 